\title{
Formation of agglutinated cysts by the foraminiferan Sphaeroidina bulloides on the Porcupine Abyssal Plain (NE Atlantic)
}

\author{
Paris V. Stefanoudis ${ }^{1}$ (D) $\cdot$ Andrew J. Gooday ${ }^{2}$
}

Received: 9 August 2015 /Revised: 14 December 2015 / Accepted: 16 December 2015 /Published online: 19 January 2016

(C) TheAuthor(s)2016.ThisarticleispublishedwithopenaccessatSpringerlink.com

Benthic foraminiferal species sometimes produce a covering made of sediment and detrital material around their tests (shells). These sedimentary envelopes, termed 'cysts', have been observed in a number of species, from organic-walled and agglutinated to calcareous (e.g., Linke and Lutze 1993; Cedhagen 1996; Gross 2000, 2002; Gooday and Hughes 2002; Heinz et al. 2005). However, almost all published records of this phenomenon originate from coastal or bathyal settings, and there are very few examples from abyssal depths, i.e. deeper than $3500 \mathrm{~m}$.

During the analysis of Megacorer samples $\left(25.5 \mathrm{~cm}^{2}\right.$ surface area, formalin-buffered, $0-1 \mathrm{~cm}$ sediment horizon, $>150 \mu \mathrm{m}$ fraction) collected in the area of the Porcupine Abyssal Plain Sustained Observatory (PAP-SO) in the northeast Atlantic $\left(49^{\circ} \mathrm{N} 16.5^{\circ} \mathrm{W}, 4850 \mathrm{~m}\right.$ water depth), we observed benthic foraminifera that had created partial or complete muddy coatings. Most belonged to Sphaeroidina bulloides d'Orbigny, 1826 (Fig. 1), and a few to Melonis barleeanus (Williamson, 1858). The S. bulloides cysts occasionally incorporated juvenile planktonic foraminiferal tests $(<50 \mu \mathrm{m})$, and always

Communicated by P. Martinez Arbizu

Paris V. Stefanoudis

p.v.stefanoudis@soton.ac.uk

1 Ocean and Earth Science, National Oceanography Centre Southampton, University of Southampton Waterfront Campus, European Way, Southampton SO14 3ZH, UK

2 National Oceanography Centre, University of Southampton Waterfront Campus, European Way, Southampton SO14 3ZH, UK included one or more flexible agglutinated tubes (20$35 \mu \mathrm{m}$ wide, $140-400 \mu \mathrm{m}$ long) that extended out of the main structure (Fig. 1a-e). There was no evidence of the presence within the cysts of microscopic organisms, comparable to the ciliates and nematodes observed by Linke and Lutze (1993) inside the cysts of Elphidium incertum.

Although most of the $S$. bulloides cysts were unattached, some were sessile on large $(>300 \mu \mathrm{m})$ planktonic foraminiferal tests (e.g., Fig. 1b) that dominated the sand fraction of the PAP-SO sediments. All of the specimens found forming cysts were 'live' (i.e. stained with Rose Bengal) and filled with green-coloured cytoplasm (Fig. 1g), which indicates that they were feeding on freshly deposited phytodetritus that formed patchy deposits on the seafloor at the time of sampling (Durden et al. 2015).

Encystment by $S$. bulloides was observed by Linke and Lutze (1993) from the Guinea Basin, off Ivory Coast ( $\sim 700 \mathrm{~m}$ water depth). However, ours is the first record of this behavioural trait in $S$. bulloides at a much deeper abyssal site, despite the fact that this species has been recorded in other abyssal locations (Murray 2013; Table 16 in Supplementary Material). The only other example of which we are aware of an abyssal foraminiferal species creating a cyst is that of Quinqueloculina sp., also from the Porcupine Abyssal Plain (Gooday et al. 2010). Our analysis of 'live' benthic foraminifera in 16 Megacorer samples from the PAP-SO area revealed that $S$. bulloides had a density of 0-7 individuals per sample (i.e. up to 3.1 individuals per $10 \mathrm{~cm}^{2}$ ), or $0-6 \%$ of the 'live' assemblage. These values are consistent with those recorded in other studies (Murray 2013, Table 2 therein). Overall, one of every four 'live' specimens of $S$. bulloides encountered in our samples had created a cyst. 

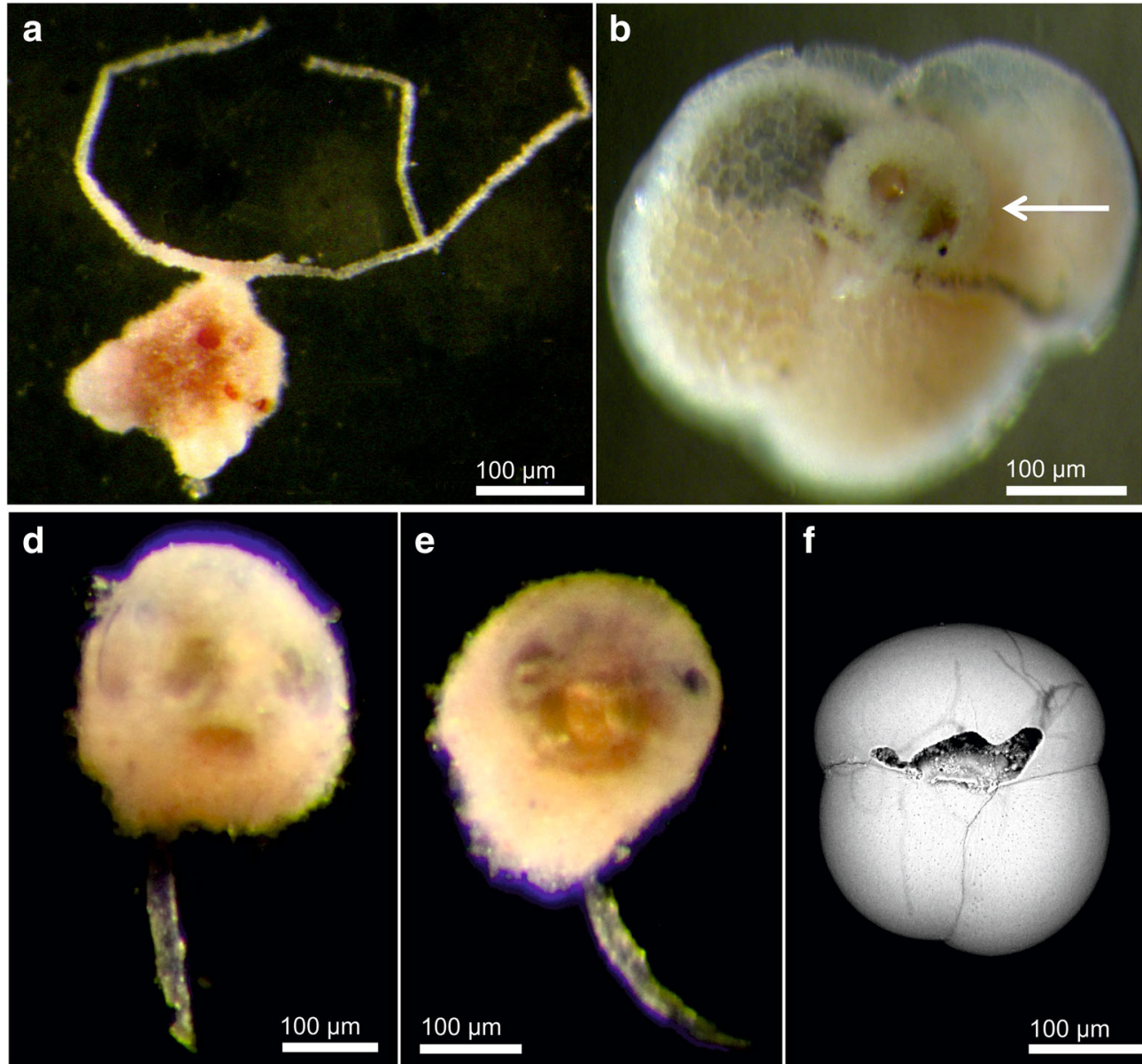

Fig. 1 Sphaeroidina bulloides forming mud cysts. Reflected light images (a-e); scanning electron microscopy image (f); transmission light image (g). Unattached, complete cyst incorporating juvenile planktonic foraminiferal tests $(<50 \mu \mathrm{m})$ and including long (approx. $400 \mu \mathrm{m})$ tubes (a). Partial mud cyst (indicated by an arrow) sitting on top of large

The benefit of agglutinated cysts to the foraminifera is unclear, although it has been speculated that they serve various functions related to feeding, reproduction, growth and protection (Gross 2002; Heinz et al. 2005). As sediments on the Porcupine Abyssal Plain are well oxygenated and situated above the carbonate compensation depth, encystment of $S$. bulloides in this area is unlikely to serve the purpose of protection against corrosion, as has been proposed by Murray (1991). The tubes arising from the cysts of this species may function as a guide or anchor for its pseudopodia, as suggested for Cibicides refulgens from an Antarctic coastal habitat (Alexander and DeLaca 1987) and $C$. wuellerstorfi from the bathyal Mediterranean (Heinz et al. 2005). Individuals of Miliolinella subrotunda collected at depths to $1419 \mathrm{~m}$ in the Atlantic Ocean constructed a sediment cyst extending into a tubular structure (up to $6 \mathrm{~mm}$ long) that elevated the test above the sediment surface, thus providing access to high-quality suspended food particles advected by lateral currents
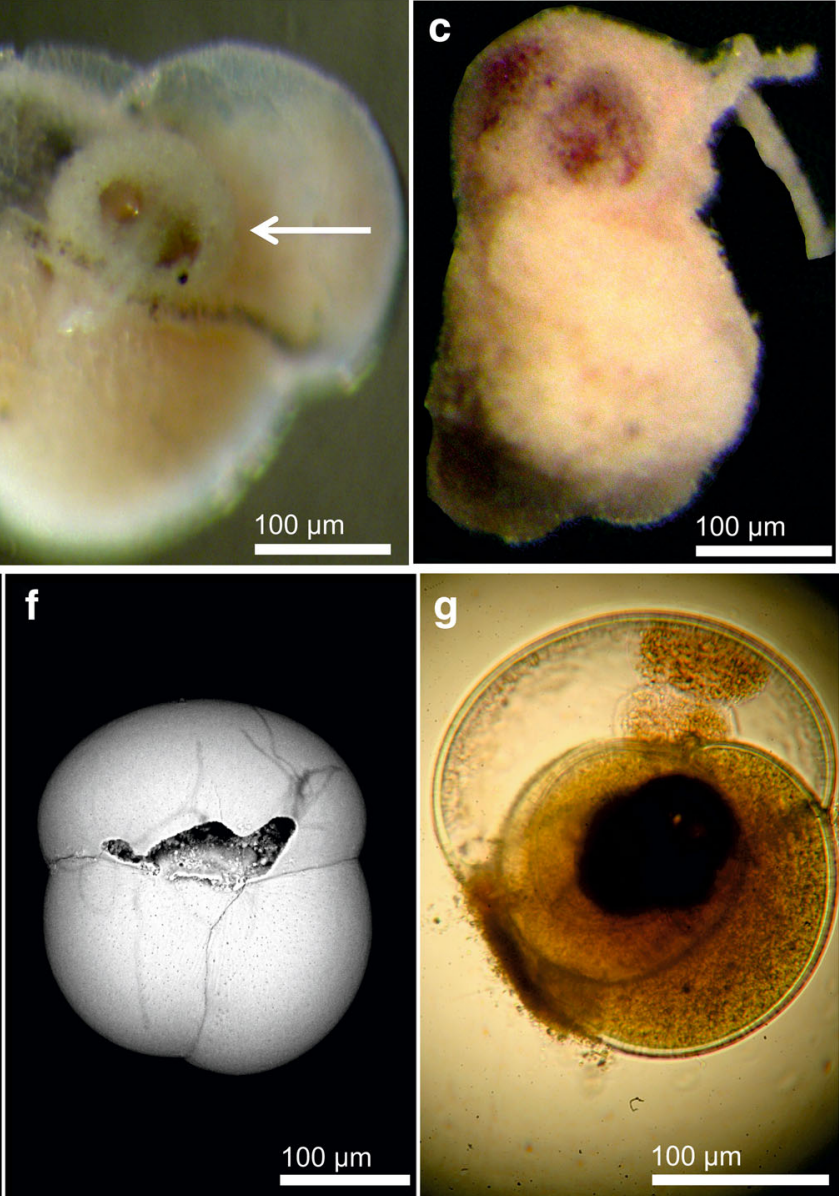

(>300 $\mu \mathrm{m})$ planktonic foraminiferal test (b). Partial mud cyst attached to planktonic foraminiferal tests $(\mathbf{c})$. Specimen with partial muddy coating and short tube (approx. $200 \mu \mathrm{m})(\mathbf{d}-\mathbf{e})$. Specimens of $S$. bulloides after the removal of the cyst $(\mathbf{f}-\mathbf{g})$. Note that the interior is filled with green protoplasm (g)

(Altenbach et al. 1993). However, this structure clearly serves a different function from that of the flimsy, sometimes branched tubes described here.

Acknowledgments We thank the captain and the crew of the R.R.S. James Cook and the scientists participating in JC062 for their assistance with the field operations. One of us (P.V.S.) is jointly funded by NERC and the School of Ocean and Earth Sciences, University of Southampton. This research contributes to the NERC-funded efforts of the Autonomous Ecological Survey of the Abyss project (AESA; NE/H021787/1) and the Porcupine Abyssal Plain Sustained Observatory Programme.

Open Access This article is distributed under the terms of the Creative Commons Attribution 4.0 International License (http:// creativecommons.org/licenses/by/4.0/), which permits unrestricted use, distribution, and reproduction in any medium, provided you give appropriate credit to the original author(s) and the source, provide a link to the Creative Commons license, and indicate if changes were made. 


\section{References}

Alexander SP, Delaca TE (1987) Feeding adaptations of the foraminiferan Cibicides refulgens living epizoically and parasitically on the Antarctic scallop Adamussium colbecki. Biol Bull 173:136-159. doi:10.2307/1541868colbecki

Altenbach AV, Heeger T, Linke P, Spindler M, Thies A (1993) Miliolinella subrotunda (Montagu), a miliolid foraminifer building large detritic tubes for a temporary epibenthic life-style. Mar Micropaleontol 20:293-301. doi:10.1016/0377-8398(93)90038-Y

Cedhagen T (1996) Foraminiferans as food for cephalaspideans (Gastropoda: Opisthobranchia), with notes on secondary tests around calcareaous foraminiferans. Phuket Mar Biol Cent Spec Publ 16:279-290

Durden JM, Bett BJ, Jones DOB, Huvenne VAI, Ruhl HA (2015) Abyssal hills - hidden source of increased habitat heterogeneity, benthic megafaunal biomass and diversity in the deep sea. Prog Oceanogr 137:209-218. doi:10.1016/j.pocean.2015.06.006

Gooday AJ, Hughes JA (2002) Foraminifera associated with phytodetritus deposits at a bathyal site in the northern Rockall Trough (NE Atlantic): seasonal contrasts and a comparison of stained and dead assemblages. Mar Micropaleontol 46:83-110. doi:10.1016/S0377-8398(02)00050-6
Gooday AJ, Malzone MG, Bett BJ, Lamont PA (2010) Decadal-scale changes in shallow-infaunal foraminiferal assemblages at the Porcupine Abyssal Plain, NE Atlantic. Deep-Sea Res II 57:13621382. doi:10.1016/j.dsr2.2010.01.012

Gross O (2000) Influence of temperature, oxygen and food availability on the migrational activity of bathyal benthic foraminifera: evidence by microcosm experiments. Hydrobiologia 426:123-137. doi:10.1023/ A: 1003930831220

Gross O (2002) Sediment interactions of foraminifera: implications for food degradation and bioturbation processes. J Foraminifer Res 32: 414-424. doi:10.2113/0320414

Heinz P, Geslin E, Hemleben C (2005) Laboratory observations of benthic foraminiferal cysts. Mar Biol Res 1:149-159. doi:10.1080/ 17451000510019114

Linke P, Lutze GF (1993) Microhabitat preferences of benthic foraminifera - a static concept or a dynamic adaptation to optimize food acquisition. Mar Micropaleontol 20:215-234. doi:10.1016/03778398(93)90034-U

Murray JW (1991) Ecology and palaeoecology of benthic foraminifera. Longman Scientific \& Technical, New York

Murray JW (2013) Living benthic foraminifera: biogeographical distributions and the significance of rare morphospecies. J Micropalaeontol 32:1-58. doi:10.1144/jmpaleo2012-010 